\title{
LUZES NÓRDICAS SOBRE A TEORIA ORGANIZACIONAL
}

\section{Charles Kirschbaum}

Doutorando em Administração de Empresas pela FGV-EAESP.

E-mail: kircharles@gvmail.br

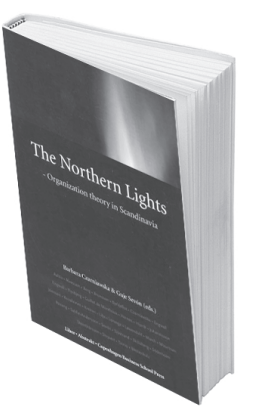

THE NORTHERN LIGHTS: ORGANIZATION THEORY IN SCANDINAVIA

De Barbara Czarniawska e Guje Sevón (Eds.)

Trelleborg: Berling Skogs, 2003. 471 p.
The Northern Lights, organizado pelas pesquisadoras Barbara Czarniawska e Guje Sevón, tem como objetivo divulgar a produção escandinava atual em teoria organizacional. Curiosamente, como aponta um dos colaboradores do livro, "luzes do norte" pode significar tanto a conhecida aurora boreal quanto a herança artística escandinava. Sob a perspectiva da aurora boreal, vemos a contribuição escandinava para a teoria organizacional como um difuso conjunto de luzes que iluminam o fenômeno organizacional a partir de múltiplos ângulos. Quando lançamos um olhar crítico a esse conjunto de textos, podemos questionar a originalidade da sua elaboração teórica, a existência de uma identidade única na pesquisa nórdica, a aplicabilidade dos resultados ou das metodologias desenvolvidas além da Escandinávia (especialmente no Brasil), e até mesmo a representatividade dos textos escolhidos. Nessa resenha, são abordadas essas questões, as metodologias apre- sentadas na obra e os resultados alcançados pelos seus autores.

A primeira parte do livro, "History Lives", posiciona o leitor frente a uma Escandinávia em transição, na qual, segundo Byrkjeflot, o "funcionalismo socialista" começa a conviver com influências capitalistas, principalmente americanas e alemãs. Para Tainio e Lilja, essa tensão entre visões de mundo, que sugere uma ruptura potencial da ordem social vigente, é atenuada pelo reforço dos valores democráticos nórdicos: cidadania e constitucionalismo. O leitor brasileiro talvez venha a considerar essa primeira parte exótica: como reconciliar a experiência dos países nórdicos, que souberam preservar direitos sociais, com a experiência brasileira, que busca consolidar sua democracia e suas instituições em um ambiente turbulento? Ao final da leitura dessa parte do livro, provavelmente o leitor ficará com a sensação de que a experiência nórdica constitui um espelho invertido da experiência brasileira.
Essa sensação de estranhamento pode ser atenuada na segunda parte do livro, "Re-phrasing Organizational Theory", na qual os autores buscam novas perspectivas para fenômenos organizacionais tradicionais. Em sintonia com a primeira parte do livro, visões "humanísticas" parecem conviver e se reconciliar com visões "instrumentais". Para Hjorth, Johannisson e Steyaert, o Homo aconomicus convive com o Homo ludens, gerando narrativas alternativas da vida organizacional. Segundo Engwall, Steinthórsson e Söderholm, a organização burocrática, estática e hierárquica, convive com a organização ligada a projetos, fluida e "adhocrática". Competição e cooperação são conectadas no próprio estilo escandinavo de fazer negócios. Mesmo a teoria crítica do sueco Mats Alvesson, de inspiração frankfurtiana, traz ares de reconciliação: fornece-nos esperanças de microemancipações no cotidiano, sem necessariamente levar a uma ruptura com a razão instru- 
mental. Por sua vez, a emancipação da mulher escandinava se dá formalmente, pela conquista de maiores direitos, mas também informalmente, por meio de sua absorção nas redes de executivos, o que é analisado por Aaltio e Kovalainen. Talvez, para os brasileiros, que vêem na Escandinávia um paradigma radicalmente diferente de gestão, a reconciliação entre o instrumental e o humanístico pareça um pouco frustrante. Aqueles que buscavam um "novo paradigma" de gerenciamento, caracterizado por um humanismo de fulgurosa luminosidade, talvez encontrem luzes mais sutis, e promessas mais conciliatórias que radicais em relação ao pensamento organizacional.

A terceira parte do livro, "Coming to Grips with Current Phenomena", talvez contenha a contribuição mais significativa dos autores. Novos fenômenos organizacionais são identificados. São também descritos diversos paradoxos que não são necessariamente resolvidos, ainda que a idéia de reconciliação não seja totalmente descartada. Brunsson, por exemplo, identifica a "hipocrisia organizacional" como perigosa, mas também necessária para a própria vida organizacional. Kreiner e Mouritsen, por sua vez, mostram que a expansão dos sistemas de gestão do conhecimento constitui ao mesmo tempo foco de resistência por parte dos funcionários, que aprendem a burlar seus mecanismos. Já Sahlin-Andersson e Sevón prestam um grande serviço à teoria da inovação ao desmistificar a dicotomia entre imitação e inovação. Paradoxalmente, inovações podem vir da imitação, e nenhuma cópia perfeita é possível sem algum grau de inovação. Ainda na linha dos paradoxos, Olof-Berg mostra como o pensamento mágico e o pensamento racional são interdependentes em um mundo de incerteza e crescente complexida- de. Em tom conciliatório, Hernes propõe que consolidação e mudança sejam sintetizadas em um terceiro pólo. Da mesma forma, Monthoux e Sjöstrand mostram como o estético e o instrumental são articulados por gestores "multirracionais". Czarniawska e Sköldberg também tentam a via da articulação, se não da síntese, de diversas metodologias de pesquisa: por meio da análise lingüística, defendem a análise da fronteira entre "modelos formais" e "narrativas". Finalmente, vê-se em Flyvbjerg a tentativa de incorporação da busca do "Bem" nas práticas organizacionais, por meio da recuperação da phronesis aristotélica.

Provavelmente, nesse ponto da obra o leitor terá desenvolvido uma percepção segundo a qual a escola de teoria organizacional escandinava é eclética em suas bases teóricas justamente por se arriscar a propor reconciliações ou acentuar as tensões em uma vasta gama de teorias. Essa sensação é reforçada por Jönsson ao ressaltar a baixa ortodoxia dos pesquisadores na sua filiação a escolas de pensamento. Se na primeira parte do livro o tom predominante era o de reconciliação, dada a mediação pela dimensão política, nesse ponto da obra o estilo que ganha predominância é o do paradoxo. E talvez essa seja a maior contribuição de todo o trabalho: a identificação daqueles paradoxos que talvez não encontrem reconciliações triviais.

A parte final do livro contém artigos sobre a produção acadêmica escandinava, compreendendo estatísticas básicas, como indicadores quantitativos de produção, temas tratados etc. Nesse esforço de preparação de um inventário, dois aspectos podem interessar ao pesquisador brasileiro: a origem teórica das citações e o grau de referência entre acadêmicos escandinavos. É grande a influência das ciências sociais, especialmente ciên- cia política, sobre os acadêmicos escandinavos. E segundo Engwall, mesmo se mantendo fortes as influências insulares e americanas, é intensa a referência interna entre os acadêmicos escandinavos.

O livro é concluído com um instigante comentário de James March. Na opinião desse renomado pesquisador, a obra faz jus ao segmento mais humanista da academia nórdica, deixando de lado contribuições importantes com abordagens positivistas e neopositivistas. Dentro desse projeto de caráter humanista, no entanto, March elogia seus colegas nórdicos por se aventurarem a explorar a fronteira da teoria, suas dimensões políticas e a crítica à racionalidade instrumental. Caminho arriscado, talvez pouco tentado nos países de maior tradição de pesquisa em gestão, mas necessário para o futuro da disciplina.

Em relação aos questionamentos esboçados no início desta resenha, não parece haver uma preocupação dos pesquisadores nórdicos em oferecer um paradigma alternativo ao americano, francês ou alemão. Ao contrário, o que parece haver é a busca do diálogo com outras comunidades científicas, procurando-se expandir as possíveis abordagens para a incorporação da dimensão política e da dimensão crítica dentro da vida organizacional.

Por outro lado, a universalização de seus resultados não é imediata. O diálogo com a pesquisa de teoria organizacional no Brasil, por exemplo, provavelmente seria caracterizada pelo estranhamento que experimentamos em relação à realidade e identidade de nossos colegas nórdicos. Estranhamento, ao nos depararmos com países de forte tradição democrática e direitos sociais consolidados; e identidade, ao pensarmos na aventura da criação de teoria que não apenas vá além, mas tente a reconciliação com a abordagem instrumental. 